\title{
Varietal Effects on the Nutrient Composition of \\ Saccharum Officinarum
}

\author{
Chuku, E. C. \\ Department of Plant Science and Biotechnology, \\ Rivers State University Port Harcourt, Nigeria. \\ Emiri, U. N. \\ Department of Agricultural Education, \\ Isaac Jasper Boro College of Education, Sagbama, \\ Bayelsa State Nigeria.
}

Received: July 17, 2018

doi:10.5296/jas.v6i3.13554
Accepted: August 3, 2018

URL: https://doi.org/10.5296/jas.v6i3.13554

\begin{abstract}
Studies on the varietal effects on the nutrient composition of Saccharum officinarum were carried out in the Department of Plant Science and Biotechnology and the Food Science and Technology Laboratories in Rivers State University. The sugar components assessed were glucose, fructose and sucrose. Sucrose was highest in both varieties compared to others. Nevertheless, the yellow variety had higher total sugar content (82. 9 \pm 0.00$)$. The assessment of mineral composition of $S$. officinarum showed that the red variety had higher values for all the parameters namely calcium, sodium, iron, chlorine, copper, phosphorus and magnesium with an exception in potassium, sulphur and carboxylic acid which were higher in the yellow variety. It was also observed that vitamins $\mathrm{A}$ and $\mathrm{C}$ values were higher in the red variety. The proximate analysis indicated that the red variety had higher values for carbonate ash, cane fibre, solid bagasse, soluble solid and salt. However, moisture (76.5 \pm 0.02$)$, protein $(0.71 \pm 0.01)$ and juice fibre $(0.8 \pm 0.01)$ were higher in the yellow variety.
\end{abstract}

Keyword: Variety, effect, nutrient composition and Saccharum officinarum 


\section{Introduction}

Saccharum officinarum L., commonly known as sugarcane is a monocot belonging to the grass family Poaceae. Literature has it that the grass cane originated from Southeast Asia (Singh et al., 2010) it was also reported that the cane plant was distributed by the Spanish into the new world. However, it is now grown in the subtropical and tropical regions with relevant economic value (Jangpromma et al., 2010). S. officinarum is a perennial grass usually found growing in cluster. The stems of sugarcane vary in colour and can attain a height of 5meters with intervals of nodes and internodes. The stems are also known to be strong. Leaves of sugarcane are green, elongated, and linear and can grow up to 30 to $60 \mathrm{~cm}$. Ekpelikpeze et al (2016) was able to characterize the various varieties of $S$. officinarum based on their stem colour, viz: black stem, wine red stem, green stem, yellow stem, red stem and dark green stem. The stem is mainly consumed by chewing the stem palp to extract the juice.

The vast production of sugarcane in Nigeria was reported in the Northern region and Nigeria noted to be the second largest sugarcane producing country in West Africa (Sulaiman et al., 2015). Also, soil conservation and organic matter enrichment through S. officinarum cultivation has also being reported (Bell et al., 2001).

The plant is so cherished because of its nutritional nature and was reported to contain mineral, vitamin B6, carbohydrate and fiber (Archimede et al., 2011). This was supported by the research of Williams et al (2016), as they implicated the presence of moisture, carbohydrate, fibre, magnesium, potassium, calcium and some phytochemicals like alkaloid, saponin, tannin and flavonoid in S. officinarum.

Nevertheless, it has also been reported that sugarcane possesses medicinal value as it has been traditionally used in Nigeria to threat several illness including haemorrhoids (Suresh-Kumar et al., 2010). This which may be attributed to its phytochemical constituents (Kadm et al., 2008). S. officinarum medicinal significance was also supported by Williams et al., (2016) as it displayed antimicrobial response against Escherichia coli, Klebsiella pnuemoniae, Staphylococcus aureus, Pseudomonas aeruginosa, Aspergillus fumigatus and Candida albicans. More so, Sepideh (2016) indicated antioxidant activity, immunotherapeutic effect, anti-inflammation, hepatotoxicity, anti-obesity and anti-malaria properties of $S$. officinarum.

However, there is little information about the effect of variety on the proximate, mineral and phytochemical constituents of S. officinarum.

Hence, this research was carried out to examine the varietal effect on the nutritional composition of Red stem S. officinarum and Yellow stem S. officinarum found within the Port Harcourt metropolis. The knowledge of this will better expose the sugar cane farmers on which of the varieties will give the best nutrient quality and should be consumed. 


\section{Macrothink}

\section{Materials and Methods}

\section{Sample Collection}

Samples of Red stem S. officinarum were obtained at Eagle Island Port Harcourt while those of the Yellow stem S. officinarum were collected from the Estate and Works Department in Rivers State University, Port Harcourt. They were all brought to the Department of Plant Science and Biotechnology for further studies.

\section{Determination of nutrient components of Saccharum officinarum}

Healthy samples of both the red and yellow stem $S$. officinarum were sent to the Food Science and Technology Laboratory for the determination of nutrient compositions.

The methods of AOAC (2005) was used to determine the level of moisture, cane and juice fibre, protein, carbonate ash, salt, solid bagasse, soluble solid, glucose, fructose and sucrose. This was also used to determine Vitamins A and C.

The atomic absorption spectrometer methods of AOAC, (1990) was adopted to determine the levels of calcium, phosphorus, chlorine, potassium, magnesium, iron, sodium and copper.

\section{Results and Discussion}

Table 1: Sugar composition of red and yellow stem varieties of S. officinarum

\begin{tabular}{lll}
\hline Parameters & Red stem $(\%)$ & Yellow stem $(\%)$ \\
\hline Sucrose & $75.00 \pm 0.00$ & $77.00 \pm 0.03$ \\
Glucose & $2.5 \pm 0.02$ & $3.6 \pm 0.10$ \\
Fructose & $3.5 \pm 0.02$ & $2.3 \pm 0.02$ \\
Total sugar & $81.00 \pm 0.01$ & $82.9 \pm 0.00$ \\
\hline
\end{tabular}

Table 2: Proximate composition of red and yellow stem varieties of S. officinarum

\begin{tabular}{lll}
\hline Parameters & Red stem $(\%)$ & Yellow stem $(\%)$ \\
\hline Moisture & $73.5 \pm 0.01$ & $76.5 \pm 0.02$ \\
Protein & $0.5 \pm 0.00$ & $0.71 \pm 0.01$ \\
Carbonate ash & $3.65 \pm 0.03$ & $3.45 \pm 0.01$ \\
Cane fiber & $17.00 \pm 0.01$ & $12.00 \pm 0.00$ \\
Juice fiber & $0.14 \pm 0.00$ & $0.8 \pm 0.01$ \\
Solid bagasse & $27.00 \pm 0.02$ & $24.00 \pm 0.02$ \\
Soluble solid & $15.00 \pm 0.04$ & $11.55 \pm 0.02$ \\
Salt & $3.65 \pm 0.02$ & $3.25 \pm 0.01$ \\
\hline
\end{tabular}


Table 3: Mineral and vitamin compositions of red and yellow stem varieties of S. officinarum

\begin{tabular}{lll}
\hline Parameters & Red stem & Yellow stem \\
\hline Calcium (mg/100g) & $0.30 \pm 0.03$ & $0.28 \pm 0.10$ \\
Magnesium (mg/100g) & $0.28 \pm 0.01$ & $0.25 \pm 0.04$ \\
Phosphorus (mg/100g) & $0.40 \pm 0.02$ & $0.35 \pm 0.16$ \\
Sulphur (mg/100g) & $0.40 \pm 0.00$ & $0.52 \pm 0.00$ \\
Chlorine (mg/100g) & $0.26 \pm 0.00$ & $0.24 \pm 0.01$ \\
Iron (mg/100g) & $0.008 \pm 0.01$ & $0.005 \pm 0.01$ \\
Copper (mg/100g) & $1.20 \pm 0.04$ & $0.23 \pm 0.03$ \\
Potassium (mg/100g) & $1.20 \pm 0.02$ & $1.30 \pm 0.01$ \\
Carboxylic acid (mg/100g) & $1.50 \pm 0.01$ & $2.05 \pm 0.02$ \\
Vitamin C (mg/100g) & $16.25 \pm 0.01$ & $15.35 \pm 0.00$ \\
Vitamin A (I. U.) & $16.30 \pm 0.00$ & $15.35 \pm 0.05$ \\
\hline
\end{tabular}

The result of sugar composition presented in Table 1. revealed that sucrose content was higher in the yellow samples and lower in the red samples. Glucose recorded higher value for the yellow stem variety and a lower value of $2.5 \pm 0.02 \%$ was recorded for the red stem variety. However, the yellow samples recorded lower value for fructose while higher value $(3.5 \pm 0.02 \%)$ was seen for the red samples. Sucrose was highest in both varieties compared to glucose and fructose. Generally, higher content of sugar $(82.9 \pm 0.00 \%)$ was recorded for the yellow stem variety of $S$. officinarum than in the red variety $(81.00 \pm 0.01 \%)$. The carbohydrate values indicated as total sugar in this study agrees with the 74 to $96 \%$ reported by Madan et al (1998) but disagrees with the $58.55 \%$ reported by Williams et al (2016).

The proximate result presented in Table 2.showed that the moisture content was higher in the yellow samples and lower value was recorded for the red samples. This was followed by a higher protein value $(0.71 \pm 0.01 \%)$ recorded for the yellow variety but a lower value of $0.5 \pm 0.00 \%$ was seen for the red variety. Notwithstanding, the carbonate ash level in the red stem was higher compared to that recorded for the yellow stem. A lower value of fibre was recorded for the yellow S. officinarum while higher value was seen for the red. Juice fibre recorded higher value for the yellow samples compared to its equivalent in the red samples. Also, increased content of solid bagasse was recorded for the red stem variety and a decreased content was seen for the yellow variety. This was followed by an increased value for soluble solid for the red samples and a reduced value for the yellow samples of $S$. officinarum. While the salt level of S. officinarum was higher in the red samples, a lower level was recorded for its equivalent in the yellow samples. The proximate result generally indicated increased values of all parameters accessed for the red variety with exceptions in moisture, protein and juice fibre which were higher for the yellow variety of $S$. officinarum. The moisture content recorded in this study is in line with the $71 \%$ reported by Williams et al (2016), although slightly higher. Nevertheless, it further disagrees with the 65.72 to $67.29 \%$ reported by Singh and Singh (2012).

The mineral and vitamin results presented in Table 3. revealed higher values of carboxylic 
acid, potassium and sulphur for the yellow stem variety and lower values of their equivalent were recorded in the red stem variety. On the contrary, increased values of calcium, magnesium, phosphorus, chlorine, iron and copper were recorded for the red samples while lower values of their equivalent were recorded for the yellow samples. Values of Vitamin A and C were higher for the red stem variety of S. officinarum when compared to those of the yellow variety. The mineral data of this study is higher than that reported by Williams et al (2016). Although, equal values of $3.0 \mathrm{mg} / \mathrm{g}$ for calcium was reported.

\section{Conclusion}

This study has revealed that sugarcane is endowed with so many nutrients that are not equally distributed among the various varieties. However, both varieties studied are good sources of sugar. S. officinarum should be produced into juice as to be taken after meal, as it possess several vitamins and minerals that are needed for a healthy living.

\section{References}

A.O.A.C., (1990). Official Methods of Analysis of AOAC International. $15^{\text {th }}$ edition. Association of Official Analytical Chemists, Washington, D.C, USA.

A.O.A.C., (2005). Official Methods of Analysis of AOAC International. $18^{\text {th }}$ edition. Association of Official Analytical Chemists, Washington, D.C, USA.

Archimede H., Xande X., Gourdine J. L., Fanchone A., Alexandre G., Boval M., Coppry O., Arquet R., Fluery J., Regneir C. and Renaudeau D. (2011). La canne a sucre etses co-produits dans I'alimentation animale. Innov. Agronomoq. 16:165-179.

Bell M. J., Halpin N. V., Orage D. N. and Haines M. (2001). Effect of compaction and trash blanketing on rainfall infiltration in sugarcane soils. Proceedings of the Australian Society of Sugarcane Technologists. 23 ${ }^{\text {rd }}$ Mackay, Queensland.pp161-167.

Ekpelikpeze O. S., Agre P., Dossou-Aminon I., Adjatin A., Dassou A. and Dansi A. (2016). Characterization of sugarcane (Saccharum officinarum L.) cultivars of Republic of Benin. International Journal of Current Research in Biosciences and Plant Biology, 3(5):147-156.

Jangpromma N., Kitthaisong S., Jaisil P. and Thammasirirak S. (2010). A proteomics analysis of drought stress-responsive proteins as biomarker for drought-tolerant sugar cane cultivars. Am. J. Agric. Biol. Sci., 6:89-102.

Kadam U. S., Ghosh S. B., Strayo D., Suprasanna P., Devasagayam T. P. A. and Bapat V. A. (2008). Antioxidant activity in sugarcane juice and its protective role against radiation induced DNA damage. Food Chem. 106(3): 1154-1160.

Madan V. K., Misra S. R., Soni N. and Solomon S. (1998). Manual of sugarcane analysis. Technical Bulletin No. 36, ILSR Lucknow.

Sepideh M. (2016). Pharmacological effects of Saccharum officinarum L. Der Pharmacia Lettre, 8(13):223-225.

Singh A. K. and Singh J. (2012). Performance of animal operated crushers. Indian J. 
Sugarcane Technolo., 27(1): 11-14

Singh A., Pant D., Korres N. E., Nizami A. S., Prasad S. and Murphy J. D. (2010). Key to issues in life cycle assessment of ethanol production from lignocellulosic biomass: challenges and perspectives. Bioresour.Technol. 101(13):5003-5012.

Sulaiman M., Abdulsalam Z. and Damisa M. A. (2015). Profitability of sugarcane production and its contribution to farm income of farmers in Kaduna State, Nigeria. Asian J. Agric. Ext. Eco. Soc., 7(2):1-9.

Suresh-Kumar C. A., Varandharajan R., Muthumani P., Meera R., Devi P. and Kameswari B. (2010). Psychopharmacological studies on the stem of Saccharum spontaneum. Int. J. Pharm. Tech. Res. 2(1): 319-324.

Williams I. O., Eridiong O. O. and Item J. A. (2016). Nutritional and antimicrobial evaluation of Saccharum officinarum consumed in Calabar, Nigeria. African Journal of Biotechnology, 15(33): 1789-1795.

\section{Copyright Disclaimer}

Copyright for this article is retained by the author(s), with first publication rights granted to the journal.

This is an open-access article distributed under the terms and conditions of the Creative Commons Attribution license (http://creativecommons.org/licenses/by/4.0/). 